\title{
Versenytársak együttmüködésének hatása a regionális gazdasági fejlődésre
}

\begin{abstract}
A tanulmány bemutatja, hogy a versenytársak együttmüködése (koopetitíció) miként határozza meg a regionális gazdasági növekedést. Koopetícióról akkor beszélünk, amikor rivális vállalatok egyszerre versenyeznek és kooperálnak egymással profitjuk maximalizálásáért, s ezáltal hálózatot alkotnak. A koopetitív hálózat a regionális gazdasági fejlődés egyik kulcseleme, ezért az írás hálózatelméleti és térökonometriai eljárások kombinálásával elemzi a gazdasági növekedést. Empirikus vizsgálatok szerint a koopetitív hálózatokban a bizalmi szint alacsony, mégis sikeresen müködnek, mert létezik a hálózatban egy központi szereplö, akiben mindenki megbízik. Ez a szereplö hidat alkot, közvetít a versenytársak között, a hálózatban ő szervezi a koopetitív interakciót. A szerző a koopetitív hálózatok gazdasági hatásának mérésére általa kidolgozott modellt is vázolja. Ez a komplex modell szintetizálja az úgynevezett fogékony-fertőzött-modellt és a helyiaggregátum-modellt, így alkalmas a koopetitív hálózati hatások és externáliák regionális terjedésének szemléltésére.* Journal of Economic Literature (JEL) kód: D62, F12, L14, L24, P13, R11.
\end{abstract}

\section{Elméleti háttér}

A verseny a modern piacgazdaság, a globalizált gazdasági rendszer egyik legfontosabb mozgatórugója. Adam Smith szerint a piac „láthatatlan keze”, míg Joseph Schumpeter szerint a piac „alkotó rombolása” szervezi, korrigálja és reprodukálja a piaci folyamatokat, kikényszeríti a piaci szereplők változásra való képességének javulását, a dinamikus adaptációt, és ezen keresztül meghatározza a gazdasági növekedést. Annak a gazdasági szereplőnek, aki képtelen a versenyben helytállni, rövid időn belül ki kell lépnie a piacról. Ez a kilépés fájdalmas a vállalkozó és munkavállalói számára, ám helyére olyan vállalat léphet, amely képes alkalmazkodni a piachoz. Mindez serkenti a gazdasági növekedést és végeredményben a jólét növekedését

* A kutatást a Pallas Athéné Geopolitikai Alapítvány finanszírozta.

Jóna György adjunktus, Debreceni Egyetem Alkalmazott Társadalomtudományi Tanszék (e-mail: jona.gyorgy@foh.unideb.hu).

A kézirat első változata 2016. szeptember 21-én érkezett szerkesztőségünkbe.

DOI: http://dx.doi.org/10.18414/KSZ.2017.1.54 
(Kornai [2010]). A neoklasszikus növekedési modellek szerint a piaci szelekció és a vállalatok közötti folyamatos rivalizálás egyensúlyban tartja és élénkíti a gazdasági növekedést. A verseny miatt a vállalatok a legjobbat hozzák ki magukból és egymásból, a cégek közötti állandó, nemegyszer önérdekkövető verseny következtében a termékek, a szolgáltatások egyre nagyobb mennyiségben, egyre jobb minőségben és egyre kedvezőbb áron jelenhetnek meg a piacon. „A verseny gazdasági jelentösége elsősorban abban áll, hogy olcsó és jó minőségü javak előállítására készteti a gazdasági élet szereplőit.” (Stiegler [1989] 25. o.)

Már több mint kétszáz éve a gazdasági fejlődés és a verseny organikus módon összekapcsolódik a közgazdasági gondolkodásban, ezért a versenyképesség is egyre fontosabbá válik. Porter a gazdasági sikert adott régióba koncentrálódó vállalatok versenyképességéhez köti, szerinte azok a vállalatok képesek folyamatosan javítani piaci pozíciójukat, amelyek a versenyben képesek felülkerekedni a másikon (Porter [1990], [1998]). A versenyképesség regionális, területi elemzése is több évtizedre tekint vissza (Lengyel [2000]). Versenyképesnek nevezzük azokat a régiókat, ahol a magas termelékenységü cégek koncentrálódnak, ezért ott a munkajövedelem és a foglalkoztatási ráta relatíve magas, a lokális jólét könnyebben elérhető a helyi társadalom tagjai számára (Krugman-Venables [1995]). Röviden, ma már a versenyképességért is folyik a verseny (Török [1999]), hiszen az ádáz, kiélezett, érdekellentétekre épülő verseny biztosítja a gazdasági növekedést.

A vállalatközi kooperáció és a verseny szinte egymást kizáró kategóriáknak tüntek az 1970-es évek növekedéselméleti megközelítéseiben. A neoklasszikus gazdaságelmélet felfogásában a kooperáció és a verseny nem valósulhat meg egyszerre valós, piaci körülmények között (Gomes-Cassares [1996]). Sőt a közgazdasági Nobel-dijas Hayek több művében érvel amellett, hogy a gazdasági szereplők önzése, az individuális gazdasági érdekek érvényesítése fontosabb, mint a kollektív érdekeké; ebben a megközelítésben az együttműködés és a verseny egymást kizárják (Hayek [1979]).

A verseny tehát nyilvánvalóan kulcsszerepet játszik a gazdaságban. Mindezek ellenére napjainkra egyre több elméleti és empirikus közgazdaságtani kutatási eredmény egyértelmüen azt mutatja, hogy a verseny mellett a gazdasági fejlődésben a vállalatközi kooperációnak is kiemelkedő szerepe van (Bengtsson-Kock [1999], Luo [2007], Chikán [2008], Ritala [2012], Koren és szerzőtársai [2014], Gnyawali és szerzőtársai [2016]). Másik megközelítésben megállapítható, hogy exogén kapacitások mellett az endogén javak is szignifikánsan meghatározzák a gazdasági fejlődést (Valentinyi [1995]). Ez a megállapítás helytálló az aktuális magyar gazdaságra is (Jóna [2016]).

Természetesen a piacgazdaságokban létrejönnek ellátási láncok, klaszterek stb., kialakul az interszektorális együttmüködés (Schulze és szerzötársai [2014]), azonban ezekben az esetekben a cégek nem egymással rivalizálnak, így a kooperáció háttérfeltételei relatíve könnyen kialakulnak, nincs szükség különösen nagy együttműködési hajlandóságra. Ez a együttmüködés szektorok között - és nem szektoron belül - formálódik, ahol a verseny elenyésző mértékben van jelen. Ezzel szemben a gazdasági versenytársak szinte sohasem müködtek együtt. Minden bizonynyal néha előfordult a gazdaságtörténetben, hogy riválisok egymással kooperáltak adott cél érdekében, ám nem ez volt a jellemző. Napjainkban azonban a vállalatközi 
együttmüködésnek ez az új formája terjed világszerte. Elsőre azt gondolhatnánk, hogy a verseny kizárja az azonos gazdasági tevékenységet végző cégek közötti kooperációt. A valóság azonban ezt nem igazolja. A versengő együttmüködés jelentős mértékben meghatározza a vállalatok versenyképességét és így közvetlenül a gazdaság fejlődését is (Corte-Aria [2016]).

Röviden, a gazdasági fejlődést jelentősen meghatározza a piaci verseny, ám ha a verseny és a kooperáció egyszerre jelenik meg az azonos gazdasági tevékenységet végző cégek kapcsolatrendszerében, $s$ a rivális vállalatok bizonyos területeken együttmüködnek, akkor a versenyképességük még tovább fokozható, ami közvetett módon hat a gazdasági növekedésre (Vega-Redondo [1996], Madhavan [2001], QuintanaGarcía-Benavides-Velasco [2004], Wilhelm [2011]). Még egyszerübben: napjainkban a riválisok profitrátája gyorsabb ütemben emelkedhet a verseny és az együttmüködés egyidejű alkalmazásával. Például a versenytársak együttmüködéséböl gazdasági előny származhat, ha közösen vásárolnak egy adott terméket, szolgáltatást stb., és együtt árkedvezményt érhetnek el, így a fogyasztó is alacsonyabb áron juthat hozzá a termékhez. Pusztán kapcsolati rendszerüket kihasználva gazdasági előnyökre tehetnek szert. Általánosságban tehát a koopetíció által a rivális cégek egymás között megoszthatják a kockázatokat és a beruházás anyagi terheit, időt takaríthatnak meg, kiadásaikat mérsékelhetik, bevételeiket növelhetik. Másként szólva, a versenytársak vállalatközi kapcsolati tökéjüket gazdasági tőkévé konvertálhatják. A vállalatközi együttműködésnek ezt az új típusát koopetíciónak nevezzük.

A koopetíció egy dinamikusan formálódó vállalatközi viszonyrendszer, amelyben konkurens (tehát azonos gazdasági tevékenységet folytató, egymáshoz földrajzilag közel álló) vállalatok egyidejüleg kooperálnak és versenyeznek egymással a nagyobb profit megszerzéséért (Brandenburger-Nalebuff [1996], Bengtsson-Kock [1999], Mariani [2007], Bengtsson-Kock [2014], Gnyawali és szerzőtársai [2016]). A koopetíció az együttműködés (cooperation) és a verseny (competition) kifejezések egyvelegéből formálódott, erőteljesen sugallva eredeti jelentésüket. Valójában az 1910-es évek elejétől ismert volt ez a fogalom a brit és az amerikai szépirodalomban, ám a közgazdaság-tudomány a közelmúltban adaptálta. Adam Brandenburger (New York University) és Barry Nalebuff (Yale University) közös könyve vezette be a koopetíció kifejezést a közgazdaság-tudomány terminológiai rendszerébe (Brandenburger-Nalebuff [1996]).

Mint láttuk, a koopetíció a vállalatközi partnerség egy új speciális típusa. Mivel partnerségen alapuló üzleti modellröl van szó, ezért a koopetitív kapcsolatban álló vállalatokat hálózatként kell definiálni. A tanulmány fö témája tehát a koopetíció hálózattudományi elemzése, ugyanis a koopetíción alapuló vállalati csoportosulást hálózatként kezeli (Czakon [2009], Czakon-Rogalski [2014]).

Emellett lényeges kiemelni, hogy minden koopetitív hálózatnak területi kiterjedése is van, a hálózat gazdasági hatása a hálózat által lefedett földrajzi területen mérhető. A koopetitív hálózat által lefedett földrajzi egységet nodális (csomóponti) régióként kell értelmezni. A nodális régió „a tér mint erőtér fogalmával azonosítható, a gazdasági tevékenységek térbeli sürüsödését veszi alapul, általában egy vagy több nagyvárost mint térbeli csomópontot és vonzáskörzetét tartalmazza.... A csomóponti régiók folyamatosan változnak, nincs pontos határuk, a gazdasági 
kapcsolatrendszer sürüsödéséből keletkeznek.” (Lengyel [2010] 37. o.) ${ }^{1}$ Mindezek értelmében a tanulmány alapvető célja, hogy azt elemezze, miként hat a koopetitív hálózat a regionális gazdasági fejlődésre.

Koopetícióról akkor beszélünk, ha legalább két azonos gazdasági tevékenységet végző vállalat bizonyos üzleti területen együttmüködik, azaz a diád a koopetitív hálózat legkisebb alapegysége (Wasserman-Faust [1994], Choi-Wu [2009], Pathak és szerzötársai [2014]). A tanulmány elfogadja a Kuratowski-tételt, amely szerint hálózatnak (még pontosabban: teljes gráfnak) kell tekinteni a két csomópontból és egy irányítatlan élből álló gráfot is (Andrásfai [1997]). A koopetíció kutatásánál hálózatnak tekintjük azt a gráfot is, amelyben legalább két csúcsot él köt össze. Ennek leginkább a multi- és transznacionális vállalatok koopetíciójában van jelentősége, mert egy multinacionális cég általában egy másik multinacionális vállalattal hoz létre közös koopetíciós üzleti modellt (kétszereplös koopetíció). Eddigi tapasztalatok szerint a kis- és középvállalatok ezzel szemben ettől nagyobb elemszámú hálózatot alkotnak.

Koopetíció kialakul, ha 1 . a cégek tulajdonjogi értelemben egymástól teljesen függetlenek, valamint 2. az együttmüködés közöttük nem kényszerböl jön létre (GnyawaliMadhavan [2001]). A koopetíció megszünik, ha csak az egyik vagy csak kevés cég képes gazdasági előnyt realizálni a közös koopetitív üzleti stratégiából. Fontos, hogy a koopetíció nem jelenti azt, hogy az érintett vállalatok minden gazdasági tevékenységben kooperálnak. Csupán bizonyos gazdasági tevékenységben dolgoznak együtt, ám ettől függetlenül a piacon továbbra is versenytársak maradnak, a konkurenciaharc folytatódik közöttük. Koopetíció során a cégek együttmüködnek versenytársaikkal, mert megértették, hogy egyedül képtelenek lennének adott gazdasági céljaikat elérni: a közös érdek (profitmaximalizálás) összeköti a riválisokat is.

A koopetíció és a kooperáció kategória közötti eltéréseket az 1. táblázat foglalja össze.

A kooperáció és a koopetíció között az alapvető különbség az, hogy a gazdasági kooperáció legtöbbször emocionálisan meghatározott, míg a koopetíció rendszerint kognitív döntéseken alapul. Ez igazán szembetűnő a döntési folyamatok és a bizalom esetében (Sanou és szerzőtársai [2015]).

Empirikus vizsgálatok elöször a koopetíció jelenségére (Luo [2004], Chen [2008], Yam és szerzőtársai [2010]), majd feltételeire és kibontakozására (Brandes és szerzötársai [2007], Mariani [2007]), napjainkban pedig folyamatjellegére (Bengtsson-Kock [1999], de Rond-Bouchikhi [2004]) és megvalósulására (Luo és szerzőtársai [2007], Luo [2007]) koncentrálnak. A koopetíció ma már valóság, ezért egyre több elemzés készül róla. Az 1. ábra a koopetícióról szóló tudományos cikkek számát mutatja be (a könyvek és a könyvfejezetek számát nem).

A gyakorlatban a versenytársak számos területen kooperálhatnak egymással, például a kockázat- és ármegosztásban, a koopetitív hálózat tagjainak koordinálásában, új piacok létrehozásában vagy a piaci expanzióban, valamint a piaci információk, a know-how és a technológiai transzferek sajátos allokációjában is (Luo [2007], Czakon [2009], Yam és szerzőtársai [2010]). A koopetíció végső célja, hogy a hálózati vállalatok

\footnotetext{
${ }^{1}$ A nodális régió rövidítése a továbbiakban régió.
} 
1. táblázat

A kooperáció és a koopetíció összehasonlítása

\begin{tabular}{|c|c|c|}
\hline Kulcsjellemzők & Kooperatív hálózat & Koopetitív hálózat \\
\hline \multicolumn{3}{|c|}{ A kapcsolat természete és célja } \\
\hline A kapcsolat természete & kollaboráció dominál & paradox: kollaboráció + verseny \\
\hline Döntési folyamat & intuitív & $\begin{array}{l}\text { intuitív és racionális („nehéz } \\
\text { megtenni, de muszáj”) }\end{array}$ \\
\hline Mindennapos tevékenység & $\begin{array}{l}\text { elsősorban az értékteremtés } \\
\text { áll a központban }\end{array}$ & $\begin{array}{l}\text { megosztott napirend + látens } \\
\text { napirend }\end{array}$ \\
\hline \multicolumn{3}{|l|}{ A kapcsolat dinamikája } \\
\hline Tanulás & közös tanulás & tanulási verseny \\
\hline Bizalom & általában magas & egyidejü bizalom és bizalmatlanság \\
\hline Feszültség a kapcsolatban & általában alacsony & általában magas \\
\hline Konfliktusmenedzsment & konfliktuskerülés & $\begin{array}{l}\text { konstruktívan kezelik a } \\
\text { konfliktusokat }\end{array}$ \\
\hline Várható járadék & kollektív járadék & szinkretikus járadék \\
\hline Várható eredmények & $\begin{array}{l}\text { győztes-győztes vagy } \\
\text { győztes-vesztes }\end{array}$ & győztes-győztes \\
\hline Kockázatok & $\begin{array}{l}\text { stagnálás és a megújulás } \\
\text { hiánya }\end{array}$ & $\begin{array}{l}\text { aszimmetrikus tanulás és a tudás } \\
\text { jogellenes, hütlen felhasználása }\end{array}$ \\
\hline
\end{tabular}

Forrás: Sanou és szerzőtársai [2015] 3. o.

közösen meghatározott céljaikat elérjék, az endogén és exogén erőforrásaikat hatékonyabban kihasználják, és javítsák versenypozíciójukat (Ritala [2012]).

Megkülönböztetjük a horizontális és vertikális koopetíciót (Czakon [2009]). A kínálatorientált megközelítés a horizontális koopetíciót vizsgálja, amikor versengő cégek között alakul ki koopetitív viszony, míg a kínálat- és a keresletorientált megközelítés sajátos keveréke a vertikális koopetícióval, az eladók és vásárlók alkudozásának kérdéskörével foglalkozik (Tindström [2009], Lacoste [2012]). Ez a tanulmány kizárólag a horizontális koopetíció jellemzőit vizsgálja.

A koopetitív hálózatok kifejlődése szempontjából megkülönböztetjük a szándékos koopetíciót (deliberate coopetition) és a nem szándékos koopetíciót (unintentional coopetition) (Czakon [2009]). A szándékos koopetíció azt jelenti, hogy a vállalati menedzsment tudatosan, korábbi jó példák adaptálásával hoz létre és épít fel koopetitív hálózatot. A nem szándékos koopetíció ezzel ellentétben olyan informális úton, alulról felfelé irányuló szerveződés (bottom-up) keretében jön létre, amelyben a tagok nem tervezik, szervezik menedzsmenttudományi eszközökkel a koopetitív hálózatot, hanem ,józan paraszti ésszel”, külső befolyás nélkül felismerik, hogy bizonyos gazdasági területen megéri a konkurenciával együttmüködni. A nem szándékos koopetíció spontán módon, a vállalatok önkéntes együttmüködésén alapul, a cégek között nincs formális partnerségi szerződés. Erre jó példa az Amazon (www.amazon.com - Ritala és szerzőtársai [2014]), valamint egy nyíregyházi és egy budapesti koopetitív hálózat kifejlődése (Jóna [2016]). 
1. ábra

A koopetícióval foglalkozó tudományos cikkek száma

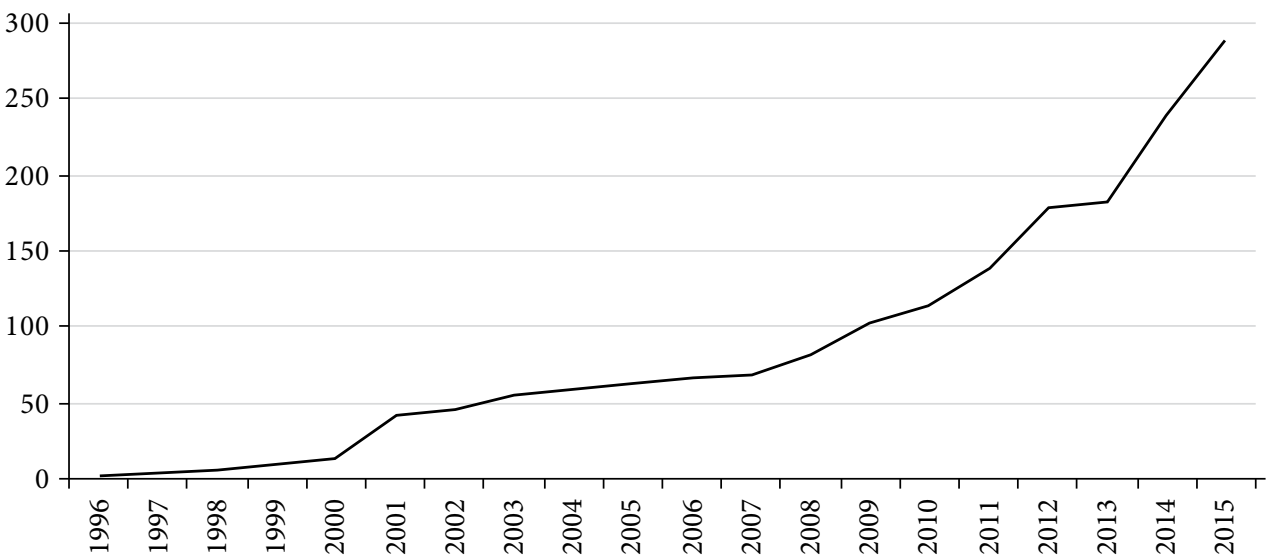

Forrás: ABI/INFORM, EBSCO, SSCI/Web of Science, www.scholar.google.com.

Természetesen azokat a vállalkozói hálózatokat igazán könnyü feltérképezni, amelyek formális szerződést is kötnek egymással, ezek tagjai pontosan megismerhetők. Az informálisan müködőket azonban nehéz észrevenni és vizsgálni. A nem szándékos koopetíciót alkotó hálózatok pedig éppen ilyenek.

A koopetíció létrejöhet informális (Bengtsson-Kock [1999], [2000]) és formális keretek között (Wang-Krakover [2008], Hung-Chang [2012], Jóna [2016]) is, mindkettőre találunk példát a nemzetközi gyakorlatban. Formális koopetícióra általában akkor van szükség, ha két különböző gazdasági erővel, tőkével rendelkező rivális cég között alakul ki partnerségi viszony. Ebben az esetben a gyengébb vállalat számára jelent némi garanciát az együttmüködési szerződés. Szerződés nélkül is kialakulhat koopetíció - rendszerint a nem szándékolt koopetitív hálózatok esetében (Kylanen-Rusko [2011]).

A közgazdasági kutatások már több évtizede foglalkoznak azzal, hogy a bizalomnak milyen funkciói vannak a gazdasági folyamatokban (Lyon [2000], Győrffy [2012], Major [2014], Ha és szerzőtársai [2016]). Ez a kérdéskör szerves része a hálózatosodásnak is, hiszen a vizsgálatok direkt vagy indirekt formában azt sugallják, hogy a bizalom megerősíti a vállalkozói hálózatot, a bizalmatlanság pedig dezintegrációs hatást gyakorol rá (Lyon [2000], Murphy [2006], Galkina-Chetty [2015], Collier [2015], Ha és szerzőtársai [2016]). Ezekben a kutatásokban a munkahipotézis rendszerint az, hogy ha a gazdaság szereplői hisznek egymásban és egymásnak, akkor a hálózati evolúció könnyebben elkezdődhet, és a hálózati hatás felerősödhet (Vega-Redondo [1996]). És fordítva: ha bizalmatlanság uralkodik a vállalkozók között, előfordulhat, hogy nem is jönnek létre hálózatok, amelyek a gazdasági növekedés egyik kiemelten fontos motorjai, így az adott térségben marad a stagnálás, esetleg a romlás.

Ez a megállapítás elméletileg helytálló interszektorális partnerség esetén, azonban a koopetitív hálózatokban az egymásba vetett bizalomnak csak nagyon alacsony szintje 
mérhető. Ez természetes is, hiszen a versenytársban, a riválisban nagyon nehéz megbízni, életszerütlen lenne azt várni a konkurens vállalkozóktól, hogy bízzanak meg egymásban. A konkurensek eddigi kapcsolatai az érdekellentétről, a kíméletlen versenyről és a szembenállásról szóltak. A kirívóan magas bizalmatlanság ellenére mégis egyre növekvő számban jönnek létre alulról szerveződő koopetitív hálózatok. Ahhoz, hogy a koopetitív hálózatok sajátosságait megértsük, ki kell szélesíteni azokat a gazdaságelméleti alapvetéseket, amelyek segítségével a bizalom funkcióit modellezik a gazdaságban. Eddig az volt a kiindulópont, hogy csak olyan gazdasági szereplők között indulhat el a hálózatosodás, akik között a bizalom alapjai megtalálhatók, hiszen a hálózatosodás alapja a bizalom. Ezzel szemben ma már azok a koopetitív hálózatok is képesek gazdaságilag hatékonyan működni, amelyek tagjai között érdekellentét, majdnem teljes bizalmatlanság áll fenn. A kérdés tehát az, miként jöhetnek létre és hogyan müködhetnek koopetitív hálózatok ekkora bizalmatlanság mellett.

Az eddigi empirikus tudományos vizsgálatok egyértelmüen rávilágítanak, hogy a koopetitív hálózatok szereplői között nincs vagy csak nagyon kis számban található koopetitív interakció. Ez azt jelenti, hogy a koopetitív hálózati szereplők egymással alig vagy egyáltalán nem kooperálnak, nem kommunikálnak (a teljes hálózatok természetesen ez alól kivételek). Általában azonban minden koopetitív hálózatban van egy központi szereplö, egy olyan vállalkozó, akiben minden egyes tag megbízik (Madhavan és szerzötársai [2004], Choi-Wu [2009], Pathak és szerzötársai [2014]). ${ }^{2}$ Tehát a koopetitív hálózatban is megtalálható a bizalom, ám ennek rendkívül alacsony foka mérhetö.

Ebben a központi funkciót betöltő vállalkozóban mindannyian megbíznak, ezért ő közvetít, hidat képez a konkurensek között, ő szervezi, tervezi és koordinálja a tagok közti koopetitív tevékenységeket. Tehát a versenytársak közvetlenül nem kooperálnak egymással a korábbi rossz tapasztalataik miatt, ismerik egymást, de esetleg kapcsolatuk is elmérgesedett. Azonban érdekük az együttműködés, ${ }^{3}$ amiből saját profitjukat maximalizálhatják, ezért egy közvetítő van közöttük, akiben mindnyájan bíznak. Ezt a ritkán szőtt bizalmi hálót jól prezentálja egy hazai koopetitív hálózati taggal - Nyíregyházán - készült alábbi interjúrészlet.

„Egyszerűen gyűlölöm J. C.-t [egy konkurens vállalkozó nevét említi itt a megkérdezett személy], mert korábban többször átvert engem. Mindketten utáljuk egymást. De ismerem P. D.-t is [itt a központi szerepet betöltő vállalkozó nevét említi], aki ismeri J. C.-t is. Tudom, hogy a közös áruszállítással egy csomó pénzt takaríthatok meg, de képtelen vagyok leülni és tárgyalni J. C.-vel, ezért P. D. szervezi mindig az áruszállítást közöttünk. P. D. nagyon jó ember, bízom benne. Mindig megkér engem és J. C.-t is, hogy írjuk össze, milyen áru hiányzik, és leszervezi a közös szállítást. Még szerencse, hogy P. D. itt van és közvetít közöttünk, mert ezzel a nővel képtelen lennék együtt dolgozni. Itt van P. D. és a közös áruszállítás müködik, és így pénzt spórolunk." (Jóna [2016] 121. interjú.)

\footnotetext{
${ }^{2}$ E központi szereplő megnevezése a koopetícióval foglalkozó angol nyelvű szakirodalomban: focal firm, dominant firm, central firm vagy broker.

${ }^{3} \mathrm{Ez}$ az együttműködés a magyar koopetitív hálózatokban általában a közös áruszállításban testesül meg.
} 
Magyarországon jellemző, hogy egy központi szerepet betöltő vállalkozó (focal firm) hozza létre magát a hálózatot, ő szelektál a tagok között, ő „találja ki, építi fel" a hálózatot. Ahogy a később leírtakból majd kiderül: az amerikai és az ausztrál koopetitív hálózatok evolúciója ettől jelentősen eltér. Ezekben a régiókban ugyanis maguk a rivális vállalkozók közösen keresnek olyan központi szerepet betöltő vállalkozót, aki koordinálja koopetitív tevékenységüket.

A központi szerepet betöltő vállalkozó fontossága jól látszik, ha a koopetitív hálózat struktúráját vizsgáljuk. Az alkalmazott koopetitív hálózati modellben a csomópontok a vállalatok telephelyét, az élek pedig a koopetitív interakciót jelölik. Koopetitív hálózatokban legtöbbször a csomópontok szereplői tudatában vannak egymásnak, ismerik egymást, ám nem kapcsolódnak egymáshoz (disconnected nodes). A koopetitív kapcsolathálóban azonban létezik egy csúcs (még pontosabban: egy hub, egy koncentrátor), amit él köt össze minden hálózati elemmel. Gráfelméleti szempontból megállapítható tehát, hogy a koopetitív hálózatok topológiája skálafüggetlen, vagyis egy adott csomópontnak sok éle van, míg a legtöbb ponthoz egy vagy csak nagyon kevés él tartozik; a hub irányítja a hálózatot (Freedman és szerzötársai [2007], Barabási [2016]). A hálózat hatványfüggvény-eloszlása megmutatja, hogy a koopetitív hálózatban egy centrális, bizalmas szereplő irányítja a koopetíciót a rivális cégek között - sikeresen. Nincs szükség arra, hogy mindegyik vállalkozó bízzon egymásban, elég egyben megbízni mindegyiknek, és ez a központi szereplő közvetít a több hálózati szereplő között, hidat képez közöttük. Hálózattudományi megközelítésben: a koopetitív hálózatok klaszterezettségi együtthatója és összekapcsoltsága (connectedness) rendszerint alacsony (Barabási [2016]).

Láttuk, a koopetitív hálózatok legtöbbször hatványfüggvény-eloszlást követnek, vagyis robusztusságuk nagy. A gyakorlatban ez azt jelenti, hogy véletlen hálózati támadás esetén a koopetitív hálózatok sokáig képesek müködni, hiszen nagy valószínüséggel nem a központi szereplöt (a hubot) fogják kiiktatni, amely integrálja, összefogja az egész hálózatot. Véletlen támadások során valószínủleg azokat a csomópontokat iktatják ki, amelyeknek kevés élük van, hiszen ilyen csomópontból van a legtöbb. Ha kevés kapcsolattal rendelkező pont tűnik el a hálózatból, akkor a hálózat még képes hatékonyan müködni (Jia-Nie [2012]). Ezzel ellentétben, ha nem véletlen, hanem tudatos támadás éri a koopetitív hálózatot, vagyis ha a központi szereplöt emelik ki a hálózatból, akkor a hálózat könnyen, rövid időn belül szétesik, megsemmisül (Barabási [2016]).

Ha a koopetitív hálózat teljes hálózat lenne (minden elemet koopetitív él köt össze), akkor a véletlen támadások majdnem ugyanolyan sikerrel vernék szét a hálózatot, mint a tudatos támadás. Következésképpen a teljes hálózat robusztussága alacsonyabb, mint a skálafüggetlen architektúrát követö koopetitív hálózaté.

Hangsúlyozni kell, hogy koopetíció esetében nincs szó piacellenes összejátszásról, sem kvázi-, sem tökéletes összejátszásról, nem a „színfalak mögött” létrehozott kartellszerü megállapodásról van szó, ami egyértelmüen káros a gazdasági struktúrára, funkciókra és a növekedésre is (Jia-Nie [2012]). A koopetíció nem sérti a verseny alapvető szabályait, mert a felek nem állapodnak meg sem a termelt mennyiségben, sem az árban, amivel növelhetnék a közös profitszerzésüket. A koopetíció megjelenésével nem tűnik el a verseny a gazdaságból. Épp fordítva. A koopetíció elméleti és empirikus modellezése is bizonyítja, hogy versengő együttmüködés hatására a piac 
bővül (vagy akár új piacok jöhetnek létre), csökkennek az árak, a termelés és a foglalkoztatás javul, a bérszínvonal nő, vagyis a koopetitív stratégia a jóléti függvényre pozitív hatást gyakorol (Köhegyi és szerzőtársai [2014]).

A koopetitív hálózatok evolúcióját játékelméleti és döntéselméleti modellekkel lehet leírni. Racionális (növekedést stimuláló) döntést hoz az a vállalat, amely a versenyalapú gazdasági struktúrában bizonyos időszakonként, illetve bizonyos részterületeken együttműködik a vele versenyző másik céggel. Játékelméleti megközelítés szerint a koopetíció változó összegủ játék, amelyben a kooperáció pozitív összegü játékként, a verseny pedig nullaösszegü játékként definiálható (Pathak és szerzőtársai [2014]). Összefoglalva, a piacgazdaságban a szemet szemért (tit-for-tat) elv érvényesül, ám koopetíció hatására ez az elv enyhül, részlegesen megszünik, de nem teljesen.

\section{Koopetitív üzleti stratégiák a gyakorlatban és a koopetíciós paradoxon}

Láthattuk, a koopetíció ma már nemcsak izgalmas elméleti okfejtés, hanem az üzleti életben is egyre gyakorabban elöforduló jelenség. A kis- és középvállalatok mellett már a multinacionális cégek és leányvállalataik is felismerték, hogy a koopetíció kiaknázásával még eredményesebbé válhatnak. Koopetitív üzleti stratégiára épül napjainkban több régióban az ipari szektor, többek között a fémipar (Gnyawali és szerzötársai [2006]), a félvezetögyártás (Pathak és szerzötársai [2014]) és a gyógyszeripar növekvő hányada is (Quintana-García-Benavides-Velasco [2004]). Emellett koopetitív stratégiát alkalmaznak számos mezögazdasági, pénzügyi és a szolgáltatói szektorban is. Dubois [2015] empirikusan bebizonyította, hogy a konkurensek együttmüködése a centrum-, a félperiféria- és a perifériarégiókban is létrejöhet. A következőkben a valóságban müködő koopetitív hálózatok gyakorlati példáit és gazdasági hatásmechanizmusait foglaljuk össze.

A koopetitív stratégia egyik iskolapéldája a PSA Peugeot Citroën és a Toyota rivális autógyárak együttmüködése. Koopetíciójuk eredménye, hogy a Toyota Aygo és a Citroën C1 elemeinek kombinálásával 2005-ben megalkottak egy új városi autót, a Peugeot 107-t. A két autógyár külön-külön képtelen lett volna finanszírozni ennek fejlesztési és kivitelezési költségeit, ezért ezeket megosztották egymás között, így a városi autó tervezése és gyártása elkezdődhetett. Természetesen a bővülés gazdasági eredményeit is megosztják egymás között a fejlesztési források finanszírozásának arányában (Gwynne [2009]).

A Samsung Electronics és a Sony Corporation koopetíciója hasonlít az előzőhöz. 2004-ben egy új közös vállalkozást hozott létre a két multinacionális konkurens vállalat, hogy közösen kifejlesszék és gyártsák a síkképernyős televíziók LCD paneljeit (Gnyawali-Park [2011]). Az ok ugyanaz volt, mint az elöző esetben: a cégeknek külön-külön nem állt rendelkezésükre elegendő pénzügyi forrás ahhoz, hogy a piaci bővítést egyedül finanszírozzák, ezért a versenytársak együtt fizették az LCD-panelek bruttó költségeit. Később a bővítés hasznát a befektetéssel arányosan felosztották egymás között. A koopetíció kezdeti fázisában mindkét cég egyformán egy-egy milliárd dollárt invesztált közös vállalkozásukba, majd később ezt 
megduplázták (Gnyawali és szerzőtársai [2016]). Ugyanilyen mintára a Ford és a Toyota 2013-ban egy új hibrid autót fejlesztett ki.

A Renault és a Nissan is koopetitív üzleti stratégiával dolgozta ki saját fejlesztési és technológiai eljárásait az autógyártásban (Segrestin [2005]): az új termék fejlesztését közösen finanszírozták, az ezzel járó kockázatokat megosztották egymás között úgy, hogy egy új közös vállalkozást alapítottak. A két cég kizárólag az új termék fejlesztését finanszírozta együtt, a gyártásban, a szállításban, az értékesítésben stb. már tovább versenyeztek egymással (Gwynne [2009]). Ma már a német és a japán gépjármüiparban is egyre inkább terjed a koopetíció (Wilhelm [2011]).

Nemcsak az autógyártásban, hanem az informatikában is megjelenik a koopetíció. A Sony és a Toshiba koopetitív partnerségi együttmüködésével sikerült összegyüjteni a blu-ray lemez gyártásához szükséges anyagi és technológiai feltételeket (Christ-Slowak [2009]). Ezzel párhuzamosan a finn mobilinternetes televízió interoperabilitását is koopetítív üzleti stratégiával teremtették meg. Az interoperabilitás itt azt jelenti, hogy információcserére alkalmas eljárást fejlesztenek ki különböző technológiai eszközök között: például televízión internetes adatforgalom realizálható, a mobiltelefon a televízió távkapcsolójaként funkcionál stb. (Ritala és szerzőtársai [2009]).

Az Apple, az IBM és a Motorola is koopetitív üzleti modell szerint kezdte el fejleszteni és gyártani az RISC-alapú mikroprocesszorokat (Vanhaverbeke-Noordehaven [2001]). Továbbá ugyanez a három vállalat az Intel és a Microsoft domináns versenypozícióját ellenőrizte koopetitív keretek között. Hasonló történt, amikor a Google és a Firefox koopetíciójával sikerült kontrollálni az Internet Explorer és az Apple’s Safari elfogadhatatlan mértékűnek ítélt piaci befolyását. Koopetícióval tehát nemcsak értékteremtés és profitnövekedés valósítható meg, hanem a domináns piaci szereplők viselkedése is ellenőrizhetö (Oum és szerzőtársai [2004]). A jól ismert Amazon is nem szándékos koopetitív üzleti modellre építette növekedési stratégiáját már kezdettől fogva (Ritala és szerzőtársai [2014]), a tulajdonos szerint egyértelmüen ennek köszönhető eddigi sikerük a növekedésben.

A német tejiparban is felfedezhetők koopetitív együttműködések. Összesen 279 német mezőgazdasági vállalkozó három régióra kiterjedő koopetitív hálózatot hozott létre, hogy profitrátájukat növeljék (Schulze és szerzőtársai [2014]). Sikerességük abban áll, hogy megértették, bizonyos területeken (nem mindegyikben) együtt kell müködniük a versenytársakkal.

1997-re befejeződött a lengyel elektromosenergia-piac privatizációja és deregulációja. Ez azt jelenti, hogy az elektromos energiát nagykereskedőtől vásárolhatják meg a kiskereskedők, és ők értékesítik azt a fogyasztók számára. A konkurens kiskereskedők azonban koopetitív hálózatot alkotva egy nagyfogyasztóként jelennek meg a nagykereskedőknél, ezért árkedvezményben részesülnek, és így olcsóbban vásárolhatják meg az elektromos energiát, amihez végeredményben a fogyasztók is kedvezőbb áron juthatnak hozzá (Czakon-Rogalski [2014]).

Ha a koopetíció földrajzi terjedését elemezzük, minden kétséget kizáróan megállapítható, hogy az a skandináv területeken fordul elö legtöbbször. A rivális vállalkozások együttmüködési hajlandósága messze az európai és nemzetközi átlag felett van főként Dániában, Finnországban és Svédországban. Vannak olyan gazdasági szektorok 
(ilyen például a finn erdészeti ágazat), amelyekben szinte kizárólag koopetitív hálózatra épülő stratégiákat találunk (Rusko [2011]). Ám az Egyesült Királyság, Izrael, Lengyelország és Olaszország régióiban is kezd „divattá válni” a konkurens vállalkozások együttmüködése (Breznitz [2009]).

Nem csak Európában találkozhatunk koopetícióval, hiszen az ausztrál bortermelők közel kétharmada koopetitív hálózatban dolgozik (Choi és szerzőtársai [2010]). Itt leginkább az új borok piaci bevezetésének marketingköltségeit finanszírozzák közösen. Továbbá Új-Zélandon konkurens mezőgazdasági cégek együtt bíztak meg egy szervezőt (akinek bruttó jövedelemét közösen fizetik), hogy hozzon létre és menedzseljen egy nagy közös piacot, ahol termékeik és a fizetöképes kereslet találkozhat (Lawson és szerzőtársai [2008]). Ehhez kísértetiesen hasonló koopetitív hálózat formálódott az Egyesült Államokban 1990-ben. Kezdetben csupán hét amerikai vállalkozásból állt a hálózat, ám mára 22 amerikai tagállamban 1834 mezőgazdasági termelő kapcsolódott be egy saját maguk által konstruált koopetitív hálózatba. Céljuk, hogy új piacokat hozzanak létre közösen, ahol egymással versenyezhetnek. Az új-zélandi példától eltérően ennek a hálózatnak a koordinációját a helyi önkormányzatok (politikai szféra) végzik, vagyis az amerikai koopetitív hálózatok heterogenitása nagyobb, mint általában az európaiaké, mivel az amerikai gazdasági és politikai szereplők képesek hatékonyan együttműködni (Lyson és szerzőtársai [2008]).

Fontos látni, hogy a valóságban a koopetíciós kapcsolathálóban a riválisok közötti konfliktusok rendszeresek. Ez természetes, hiszen a konkurenciával együtt dolgozni sohasem egyszerü. A rivális vállalatok megszokták, hogy nem kommunikálnak egymással, vagy ha mégis, akkor kiélezett versenyen alapul köztük az interakció.

A koopetíció tehát egy paradoxon. Ezt nem nehéz belátni, mert azonos vagy egymáshoz közeli földrajzi egységen rivális cégek egyszerre kooperálnak és versenyeznek egymással, hogy felhalmozott vállalatközi kapcsolati tökéjüket gazdasági tőkévé konvertálhassák (Gnyawali és szerzőtársai [2016]). Ez a paradoxon feszültséget implikál a koopetícióban részt vevők közötti kapcsolatban, a szakirodalom ezt koopetíciós feszültségnek nevezi (Lado és szerzőtársai [1997], Gnyawali-Madhavan [2001], Chen [2008], Smith-Lewis [2011]). Koopetíciós feszültség leggyakrabban akkor tör felszínre, amikor a cégek hálózati pozíciója megváltozik, és az átalakulással járó konfliktusok eszkalálódnak a hálózatban (Johansson [2012]).

Hangsúlyozni kell, hogy a koopetíciós feszültség előnyös is lehet a vállalatok gazdasági teljesítményre, de csak akkor, ha ez a feszültség nem túl erős, nem kiugróan magas. Mint láthattuk, a koopetitív viszonyban álló cégek egymással szemben gyanakvók (ebből ered a feszültség közöttük), ezért folyamatos kommunikációval tisztázniuk kell céljaikat, motivációikat, döntéseiket és tetteiket. Ezállandó, tiszta szervezetközi interakciót igényel. A koopetíciós feszültség miatt végső soron kialakul egy olyan konstruktív kommunikációs folyamat, amely során az egymással szembeni kétségek, félreértések és ellentmondások folyamatosan tisztázhatók. Ezután pedig egy valódi versenyzö-együttmüködő gazdasági tevékenység végezhető (Dorn-Schweiger-Albers [2016]). Röviden: a kezelhető és irányítható koopetíciós feszültség közvetlenül és pozitívan hozzájárul a cégek gazdasági eredményességéhez (Gnyawali és szerzőtársai [2016]); a kontrollálható koopetíciós feszültség a koopetíció reprodukálásában kiemelkedő szerepet tölt be. 
Érthetőbben, a koopetíciós feszültség állandó interakcióra készteti a koopetitív hálózat szereplöit, ezáltal tisztázhatják vitás kérdéseiket. Mindez szignifikánsan meghatározza a koopetitív hálózati teljesítményt és a regionális gazdasági fejlődés pályáját.

Abban az esetben, ha a koopetíciós feszültség nagyon magas, kezelhetetlenné válik a konfliktus a hálózati aktorok között, a cégek tehetetlenné válnak, egyfajta bénultság jellemzi őket, ami rontja eredményességüket. A gyakorlatban ez a koopetitív hálózat széteséséhez, rövid időn belüli megszünéséhez vezet. Összefoglalva, a kontrollálható koopetíciós feszültség javítja, az eszkalálódott, kezelhetetlen koopetíciós feszültség pedig rontja a regionális gazdasági növekedés háttérfeltételeit. A koopetíciós paradoxonból akkor lehet gazdasági hasznot realizálni, ha a vállalkozások megtalálják az egyensúlyt a verseny és az együttmüködés között. Ennek operacionalizálására nincs standardizált formula, mivel minden koopetíciós üzleti modell más és más, a cégeknek saját maguknak kell ezt az egyensúlyt felfedezniük. Talán általánosságban megállapítható, hogy akkor alakul ki megfelelő egyensúly a valóságban, amikor egyik fél sem érzi veszélyeztetve eredményes outputját a koopetíció miatt.

A koopetíciós feszültség adekvát kezelésében föszerepet játszik a kvalifikáltabb, kifinomultabb üzleti kultúrával rendelkező vállalati menedzsment (Gnyawali-Madhavan [2001], Chen [2008], Dorn és szerzötársai [2016]). A vállalati menedzsmentnek kiemelkedő szerepe van a stratégiai rugalmasság megteremtésében, amely megfelelő egyensúlyt (right balance) teremt kooperáció és verseny között (2. ábra). A stratégiai rugalmasság azt jelenti, hogy a koopetícióban érdekelt cégek alkalmazkodóképessége és adaptációs hajlandósága relatíve magas, alkalmasak az érdekellentétek kezelésére, a kapcsolatok stratégiai ápolására (Gnyawali és szerzőtársai [2016]). Ki kell emelni, hogy a stratégiai rugalmasságot részben tervezni kell, nem lehet spontán folyamatokra bízni.

\section{2. ábra}

A menedzsment és a megfelelő egyensúly közötti kapcsolat

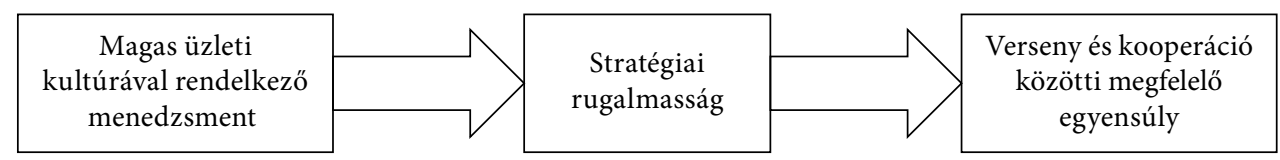

Forrás: saját szerkesztés.

\section{A koopetíció regionális gazdasági fejlődésre gyakorolt hatásának mérése}

A koopetitív hálózatok regionális gazdasági fejlődésre gyakorolt közgazdasági mérésének még nincs széles körben elfogadott módszertani eljárása. Ennek oka az, hogy a koopetíció egy egészen újszerủ gazdasági folyamat, ennek modellezése és empirikus vizsgálata csak az utóbbi néhány évben kezdődött el. Fontos azonban megjegyezni, hogy ezzel kapcsolatban már megjelent egy igazán kiváló magyar nyelvü elemzés (Köhegyi és szerzőtársai [2014]). A koopetíció empirikus vizsgálatát áttekintve, megállapítható hogy a hazai kutatók megközelítése, módszertani eljárása a legpontosabb az összes közül. 
Koopetíció során versengő vállalatok együttmüködnek, közöttük partnerségi viszony, kapcsolati háló formálódik, amelyet hálózatként kell definiálni. Nyilvánvaló, hogy a koopetíció természetét, dinamikáját, evolúcióját, funkcióit és hatásmechanizmusait hálózattudományi módszerek alkalmazásával adekvát formában lehet elemezni. Továbbá minden koopetitív hálózatnak van területi kiterjedése, ezért a hálózattudományi eljárásokat térökonometriai módszerekkel kell kombinálni (Jóna [2016], Törnroos és szerzötársai [2016]). A tanulmány ezt a szintetizált módszertani megközelítési módot igyekszik követni.

Az itt kidolgozott mérési modell célja, hogy a koopetitív hálózatok regionális gazdasági fejlődésre gyakorolt hatását operacionalizálja. Mint fentebb láttuk a modellben a csomópont a vállalat székhelyét, az összekötő él a vállalatok közti koopetitív interakciót jelöli. Él azon csomópontok között van, amelyek között koopetitív interakció zajlik.

Egy koopetitív hálózatnak hálózaton belüli és hálózaton kívüli hatását kell elkülöníteni, a modell ezt a két hatást egyszerre veszi figyelembe. A hálózaton belüli hatás azt jelenti, hogy a koopetíció hatással van a hálózathoz tartozó vállalatok gazdasági teljesítményére, míg a hálózaton kívüli hatás arra utal, hogy a hálózathoz nem tartozók is előnyt élveznek a koopetitív hálózat tevékenységéből.

Először vizsgáljuk meg a hálózaton belüli hatást! A hálózaton belüli hatást a modell két változóval operacionalizálja:

1. a hálózathoz tartozó vállalatok alkalmazottai számának változásával: $E$ (employment),

2. hálózathoz tartozó vállalatoknál megszerezhető I (income) jövedelemszinttel.

Ez a két változó a versenyképesség - CS (competitiveness) - alapmutatói, ezért a hálózaton belüli hatást a vállalatok versenyképességével azonosítja a modell; a hálózaton belüli hatás a versenyképesség változásával mérhetö.

Más megközelítésben: ha egy cég koopetíciós stratégiával megtakarít, és abból részben vagy egészben új munkahelyeket hoz létre, és/vagy emeli a foglalkoztatottak és a munkaadók jövedelmét, akkor azzal javul a vállalat versenyképessége. Vagyis Chikán [2006] vállalati versenyképességi mérésének logikáját elfogadva és alkalmazva: $C S=E+I$.

Másként, a modellben a koopetíció - CO (coopetition) - hálózaton belüli hatása úgy mérhető, hogy a koopetíció során realizált megtakarításból - $S$ (save) - kivonjuk a koopetitív tevékenységgel járó tranzakciós költségeket - TCCA (transaction costs of coopetitive actions). Koopetitív hálózatban részt vevő vállalat megtakarítását jelölje $s_{i} \in[0 ; \bar{S}] \cdot(i=1, \ldots n)$, így egy hálózat teljes megtakarításának összege adott periódusban: $S=\sum_{i=0}^{n} S_{i}$. A koopetitív tevékenységgel járó tranzakciós költségek minden hálózat esetében más és más költségeket tartalmaznak, ezt nem lehet taxatív módon minden koopetitív hálózatra vonatkozóan felsorolni, ám általános formában felírható a képlet: $C O=S-T C C A$. A koopetíció hálózaton belüli hatása negatív, ha TCCA $>C O$, és fordítva: ha TCCA $>0$, akkor a koopetíció hálózaton belüli hatása pozitív.

Csupán jelezzük: a Jóna [2016]-ban bemutatott három magyarországi koopetitív hálózatban (Tihany, Nyíregyháza, Budapest) a kooperációs fegyelem annyira nagy a hálózati tagok között, hogy ez a TCCA-t minimálisra csökkenti. A szigorú kooperációs 
fegyelem azt jelenti, hogy a vállalkozók rendkívül elszántak a partnerség mellett, ezért nem szükséges őket folyamatosan motiválni: ez csökkenti a TCCA-t.

Ugyanakkor a hálózaton kívüli hatást nyilvánvalóan hálózati externáliaként - NEX (network of externality) - kell meghatározni. A hálózati externália azt jelenti, hogy a hálózati tevékenység előnyeiből/hátrányaiból a hálózaton kívüli szereplők is részesülnek piaci ellentételezés nélkül (Kiss [2010]). Mint a definícióból kitűnik, létezik pozitív és negatív hálózati exernália. Pozitív hálózati externália akkor jön létre, ha a hálózaton kívüli szereplők fizetés nélkül előnyöket szereznek a hálózat müködéséből; ez kompenzálatlan haszon. Negatív externáliáról akkor beszélünk, amikor a hálózat a hálózaton kívüli szereplöktől áldozatot követel, vagy müködése során a hálózat valamilyen kárt okoz (Economides [1996]).

A hálózati externáliák meghatározzák egy régió endogén és exogén kapacitásait is. Az exogén erőforrások könnyen, míg az endogén kapacitások közgazdaságilag viszonylag nehezen mérhetők. A koopetitív hálózatok endogén kapacitásokra gyakorolt hatása alapvető, mert ezek a láthatatlan javak jelentős mértékben meghatározzák a regionális gazdasági fejlődés ívét (Valentinyi [1995]). Alfred Marshall számos esetben amellett érvel, hogy a gazdasági struktúrát nemcsak gazdasági, hanem a gazdasági rendszeren kívüli tényezők befolyásolják, például vállalkozók közti kapcsolatrendszer, üzleti kultúra, regionális identitás és környezet, lokális tradíciók és kultúra stb. Az immateriális erőforrások megjelenésében a hálózati externáliáknak gyakorlati jelentőségük van (Mátyás [1999] 62-84. o.]).

A magyarországi koopetitív hálózatok esetében pozitív hálózati externáliák mérhetők, jó példa erre egy tihanyi hálózat, mely közvetlenül meghatározza a hálózaton kívüli városi lakosság attitüdjét, mentalitását, a városképet és a városi infrastruktúrát is. Emellett nyíregyházi és budapesti koopetitív hálózatok a közös áruszállítás révén szignifikánsan hozzájárulnak a környezetvédelemhez és a levegö tisztaságához (Jóna [2016]). Röviden, a koopetitív hálózatok egyik alapvető tulajdonsága, hogy pozitív külső hatásukkal közjószágok fogyasztását teszik lehetővé. Másként, koopetitív hálózati externáliák az endogén $(E N)$ és exogén $(E X)$ kapacitásokat egyformán meghatározzák adott régióban $(R)$, vagyis:

$G_{N E X}=R_{E N}+R_{E X}$

Gazdasági hálózatok externáliáinak regionális terjedését eddig nagyon kevés tanulmány elemezte. A kutatók széles körében megegyezés van arról, hogy a hálózati externáliák terjedésének mechanizmusai, mintái megegyeznek a fertőzések terjedésével, ezt a kiindulópontot a modell is elfogadja. Ezért a koopetitív hálózati externáliák terjedésének modellezésére a fogékony-fertözött modellt (susceptibleinfected model) (Barabási [2016] 39-46. o.), valamint a helyiaggregátum-modellt (local-aggregate model) (Ballester és szerzötársai [2006], [2010]) szintetizáljuk. Ez a szintetizált modell alkalmas arra, hogy a koopetitív hálózat externáliái földrajzi, regionális terjedésének mintáit bemutassa.

A szintetizált modell szerint adott egy $N$ elemü koopetitív hálózat $G=\{1,2,3, \ldots, N\}$, ahol $G$ irányítatlan gráfot jelent, vagyis $d_{i j}=d_{j p}$ a hálózat $i$-edik és $j$-edik pontja közötti távolság ugyanakkora, mint a hálózat $j$-edik és $i$-edik pontja között. Feltételezzük, 
hogy a koopetitív hálózat externáliái $N$ számú szereplő között terjednek, és $t=0$ időpontban csupán egy szereplőhöz értek el a koopetitív hálózat externáliái.

A modell tehát két részhalmazból áll, egyrészt akik a koopetitív hálózat szereplői (IN), logikusan rájuk nem hatnak a koopetitív hálózati externáliák, másrészt akik nem tagjai a koopetitív hálózatnak $(O N)$, rájuk hatnak a koopetitív hálózati externáliák. $O N$ és $I N$ nemcsak részhalmazokat, hanem a bennük lévő szereplöket is jelentik. Feltételezzük továbbá, hogy a koopetitív hálózat externáliái $O N$ és IN közötti interakciókon keresztül terjednek; ha $O N$ és IN között interakció jön létre, akkor $O N$-hez eljutnak a koopetitív hálózat externáliái, így $O N$-ből $I N$-be kerül át az adott szereplő. Minden szereplőnek $\langle k\rangle$ kapcsolata van (fokszám) és $\beta$ annak valószínűsége, hogy $t$ időegység alatt a koopetitív hálózat externáliái eljutnak $I N$-töl $O N$-hez.

Amennyiben a koopetitív hálózat externáliái egyenletesen terjednek a térségben, akkor $O N(t) / N$ annak a valószínüsége, hogy egységnyi idő alatt $O N$ valamely szereplöje interakcióba lép valamely $I N$ szereplővel. Logikus, egy $O N$ szereplő $\langle k\rangle[O N(t) / N]$ számú esetben lép kapcsolatba $I N$ szereplővel egységnyi idő alatt. Mivel minden egyes $I N(t)$ szereplő $\beta$ ráta valószínűséggel lép interakcióba $O N$ szereplővel, ezért egy $d t$ hosszúságú periódusban az externáliák által elért szereplök átlagos száma $d l(t)$ (mondhatnánk, hogy ők az „externáliák által megfertőzöttek”), tehát

$\langle k\rangle \frac{O N(t) I N(t)}{N} d t$.

Az IN $(t)$ száma ebben az ütemben nő:

$\frac{d l(t)}{d t}=\beta\langle k\rangle \frac{O N(t) I N(t)}{N}$.

Amennyiben elhagyjuk az időtényezőt, akkor a fenti egyenlet átalakítható:

$\frac{d i}{d t}=\beta\langle k\rangle O N=\beta\langle k\rangle i(1-i)$.

Ebben az egyenletben a $\langle k\rangle \beta$ szorzat a koopetitív hálózat externáliáinak átadási rátáját jelöli. Ha az előző formulát átírjuk

$\frac{d i}{i}+\frac{d i}{1-i}=\beta\langle k\rangle d t$, majd minkét oldalt integráljuk, akkor megkapjuk

$\ln i-\ln (1-n)+K=\beta\langle k\rangle t$.

$\mathrm{Az} i_{0}=i(t=0)$ kezdeti feltételböl kiindulva $K=i_{0} /\left(1-i_{0}\right)$ egyenletet kapunk, az idő múlásával tehát így emelkedik IN száma:

$i \frac{i_{0} e^{\beta\langle k\rangle t}}{1-i_{0}+i_{0} e^{\beta\langle k\rangle t}}$.

Ebből kiderül, hogy koopetitív hálózat externáliái a kezdeti időszakban gyorsabban elérik ON elemeit, ekkor az externáliák exponenciális terjedése tapasztalható. Elméletileg a koopetitív hálózat externáliáinak terjedése akkor ér véget, ha mindegyik $O N$ 
szereplöt elérte, $i(t \rightarrow \infty)=1$, valamint $O N(t \rightarrow \infty)=0$, ahol $t \rightarrow \infty$ azt jelenti, hogy aki bekerült $I N$-be, az ott is marad.

Összefoglalva, a koopetitív hálózatnak hálózaton belüli és kívüli gazdasági hatásait együtt kell mérni. A fentiek figyelembevételével a vállalati versenyképesség és hálózati externália összegével együtt lehet mérni közgazdaságtani szempontból egy koopetitív hálózat regionális gazdasági fejlődésre gyakorolt hatását - EFF (effect). Röviden: $G_{E F F}+R_{C S}+R_{N E X}$.

\section{Következtetés helyett inkább kérdések}

Napjainkban a koopetitív hálózatok egyre nagyobb számban létrejönnek interregionális szinten, azonban kérdés, hogy mennyire fenntartható ez a hálózati formáció Magyarországon. Vajon meddig képes egy központi szerepet betöltő vállalkozó integrálni a versenytársakat?

Nemzetközi összehasonlításban láttuk, hogy a koopetitív hálózatok megtakarításaik révén jelentősen hozzájárulnak a regionális gazdasági növekedéshez. Ez Magyarországon is így van. Egy korábbi esettanulmányból kiderül, hogy három magyar koopetitív hálózat hét év alatt majdnem 140 új munkahelyet hozott létre, és tartott fenn pusztán a koopetitív stratégia alkalmazásával - állami források, pályázatok vagy fejlesztési támogatások segítsége nélkül (Jóna [2016]). Ha a koopetitív üzleti stratégiát nem használták volna, akkor ennyi új munkahelyet jelentős beruházással és/vagy vállalati hitellel lehetett volna létrehozni. A koopetitív hálózatok azonban állami, közösségi intervenció nélkül is megvalósítják ezt a fejlődést. Éppen ezért talán a legfontosabb kérdés a továbbiakban az, hogy a fejlesztés- és gazdaságpolitika szereplői a jövőben bevonják-e a koopetitív hálózatokat a regionális gazdaságfejlesztési elgondolásaikba.

\section{Hivatkozások}

ANDrÁsfai BÉLA [1997]: Gráfelmélet. Polygon Kiadó, Szeged.

Ballester, C.-Calvó-Armengol, A.-Zenou, Y. [2006]: Who's who in networks. Wanted: the key player. Econometrica, Vol. 74. No. 5. 1405-1417. o. http://dx.doi.org/10.1111/j.14680262.2006.00709.x.

Ballester, C.-Calvó-Armengol, A.-Zenou, Y. [2010]: Delinquent network. Journal of the European Economic Association, Vol. 8. No. 1.34-61. o.

BARABÁsi-Albert LÁszló [2016]: Hálózatok tudománya. Libri Kiadó, Budapest.

Bengtsson, M.-Kock, S. [1999]: Cooperation and competition in relationships between competitors in business network. Journal of Business and Industrial Marketing, Vol. 14. No. 3. 178-194. o. http://dx.doi.org/10.1108/08858629910272184.

Bengtsson, M.-Kock, S. [2000]: Coopetition in business network to corporate and compete simultaneously. Industrial Marketing Management, Vol. 29. No. 5. 411-426. o. http:// dx.doi.org/10.1016/s0019-8501(99)00067-x.

Bengtsson, M.-Kock, S. [2014]: Coopetition - Quo vadis? Past accomplishments and future challenges. Industrial Marketing Management, Vol. 43. No. 2. 180-188. o. http://dx.doi. org/10.1016/j.indmarman.2014.02.015. 
Brandenburger, A. M.-Nalebuff, B. J. [1996]: Co-opetition. Doubleday Currency, New York.

Brandes, O.-Brege, S.-Brehmer, P. O.-Lillecreutz, J. [2007]: Chambre separee in product development. International Journal of Automative Technology and Management, Vol. 7. No. 2-3. 163-183. o. http://dx.doi.org/10.1504/ijatm.2007.014973.

Breznitz, D. [2009]: Globalization, coopetition strategy and the role of the state in the creation of new high-technology industries. Megjelent: Dagnino, D. B.-Rocco, E. (szerk.): Coopetition strategy. Routledge Press, London-New York, 103-128. o. http://dx.doi. org/10.4324/9780203874301.

Chen, M. J. [2008]: Reconceptualizing the compatition-cooperation relationship. Journal of Management Inquiry, Vol. 17. No. 4. 288-305. o. http://dx.doi.org/10.1177/1056492607312577.

Chikán Attila [2006]: A vállalati versenyképesség mérése. Pénzügyi Szemle, 51. évf. 1. sz. 42-57. 0.

Chikán Attila [2008]: Vállalatgazdaságtan. Aula, Budapest.

Choi, P.-GARCIA, R.-Friedrich, C. [2010]: The drivers for collective horizontal coopetition. International Journal of Strategic Business Alliances, Vol. 1. No. 3. 271-290. o. http://dx.doi. org/10.1504/ijsba.2010.030427.

Choi, T. Y.-Wu, Z. [2009]: Triads in supply network. Journal of Supply Chain Management, Vol. 45. No. 1. 8-25. o. http://dx.doi.org/10.1111/j.1745-493x.2009.03151.x.

Christ, J.-Slowak, A. [2009]: Why Blu-Ray vs. HD-DVD is not VHS vs. Betamax: the coevolution of standard-setting consortia. FZID Discussion Paper, 05-2009. http://dx.doi. org/10.2139/ssrn.1626224.

Collier, P. [2015]: The cultural foundations of economic failure: A conceptual toolkit. Journal of Economic Behavior and Organization. 126. 5-24. o. http://dx.doi.org/10.1016/j. jebo.2015.10.017.

Corte, V. D.-Aria, M. [2016]: Coopetition and sustainable advantage. Tourism Management, 54. 524-540. o. http://dx.doi.org/10.1016/j.tourman.2015.12.009.

Czakon, W. [2009]: Power asymmetries, Flexibility and the Propensity to Coopete: An Empirical Investigation of SMEs' Relationships with Franchisors. International Journal of Entrepreneurship and Small Business, Vol. 8. No. 1. 44-60. o. http://dx.doi.org/10.1504/ ijesb.2009.024104.

Czakon, W.-Rogalski, M. [2014]: Coopetition typology revisited - a behavioural approach. International Journal of Business Environment, Vol. 6. No. 1. 28-46. o. http://dx.doi. org/10.1504/ijbe.2014.058022.

DE Rond, M.-Bouchikhi, H. [2004]: On the dialectics of strategic alliences. Organization Science, Vol. 15. No. 1. 56-69. o. http://dx.doi.org/10.1287/orsc.1030.0037.

Dorn, S.-SchWeiger, B.-Albers, S. [2016]: Levels, phases and themes of coopetition. European Management Journal, Vol. 34. No. 5. 484-500. o. http://dx.doi.org/10.1016/j.emj.2016.02.009. Dubois, A. [2015]: Business networks and the competitiveness of small manufacturing firms in Sweden's northern periphery. Norwegian Journal of Geography, Vol. 69. No. 3. 135-151. o. http://dx.doi.org/10.1080/00291951.2015.1040444.

Economides, N. [1996]: Network Externalities, Complementarities, and Invitations to Enter. European Journal of Political Economy, Vol. 12. No. 2. 211-232. o. http://dx.doi. $\operatorname{org} / 10.2139 /$ ssrn.2237.

Freedman, M.-Lovász, L.-Schrijver, A. [2007]: Reflection positivity, rank connectivity and homomorphism of graphs. Journal of American Mathematical Society, Vol. 20. No. 1. 37-51. o. 
Galkina, T.-Chetty, S. [2015]: Effectuation and networking internalizing SME's. Management International Review, Vol. 55. No. 5. 647-676. o. http://dx.doi.org/10.1007/ s11575-015-0251-X.

Gnyawali, D. R.-He, J.-Madhavan, R. [2006]: Impact of coopetition on firm competitive behavior. Journal of Management, Vol. 32. No. 4. 507-530. o. http://dx.doi. org/10.1177/0149206305284550.

Gnyawali, D. R.-Madhavan, R. [2001]: Cooperative networks and competitive dynamics: a structural embeddedness persepctive. Academy of Management Review, Vol. 26. No. 3. 431-445. o. http://dx.doi.org/10.5465/amr.2001.4845820.

Gnyawali, D. R.-Madhavan, R.-He, J.-Bengtsson, M. [2016]: The competition-cooperation paradox in inter-firm relationships: a conceptual framework. Industrial Marketing Management, Vol. 53. 7-18. o. http://dx.doi.org/10.1016/j.indmarman.2015.11.014.

GNYAWALI, D. R.-PARK, B. J. [2011]: Coopetition between giants: collaboration with competitors for technological innovation. Research Policy, Vol. 40. No. 5. 650-663. o. http://dx.doi. org/10.1016/j.respol.2011.01.009.

Gomes-CAssares, B. [1996]: The alliance revolution: the new shape of business rivalry. Harvard University Press, Cambridge, http://dx.doi.org/10.5860/choice.34-2251.

Gwynne, P. [2009]: Automakers hope coopetition will map route to future sales. Research Technology Management, Vol. 52. No. 2. 2-4. o.

GYőRFFY DóRa [2012]: Intézményi bizalom és a döntések időhorizontja. Közgazdasági Szemle, 59. évf. 4. sz. 412-425. o.

HA, H.-LEE, M.-JANDA, S. [2016]: Effects of economic and social satisfaction on partner trust. European Journal of Marketing, 50. No. 1-2. 78-99. o. http://dx.doi.org/10.1108/ejm-022014-0125.

Hayek, F. A. [1979]: Law, Legislation and Liberty. Vol. 3. The Political Order of a Free People. Routledge and Kegan Paul, London.

Hung, S.-CHANG, C. [2012]: A coopetition persepctive of technology alliance govenance modes. Technology Analysis and Strategic Management, Vol. 24. No. 7. 679-696. o. http:// dx.doi.org/10.1080/09537325.2012.705120.

JiA, R.-NiE, H. [2012]: Decentralization, collusion and coalmine death. APSA Annual Meeting Paper, http://papers.ssrn.com/sol3/papers.cfm?abstract_id=2104749.

JoHANsson, M. [2012]: Interaction in dynamic networks: role-playing and its implications for innovation. The IMP Journal, Vol. 6. No. 1. 17-37. o.

JónA GYörgy [2016]: Koopetitív KKV-hálózatok területi dimenziói és hatásai. Területi Statisztika, 56. évf. 1. sz. 66-88. o. http://dx.doi.org/10.15196/ts560105.

KIss FERENC LÁszló [2010]: Külső gazdaságosság (externália) a fogyasztási folyamatban. Megjelent: Valentiny Pál-Kiss Ferenc László-Nagy Csongor István (szerk.): Verseny és szabályozás. MTA Közgazdaságtudományi Intézet, Budapest, 13-68. o.

Koren Miklós-PÁl Jenő-Szeidl ÁdÁm [2014]: Cégek kapcsolati hálózatainak gazdasági szerepe. Közgazdasági Szemle, 51. évf. 11. sz. 1341-1360. o.

KoRNAI JáNOs [2010]: Innováció és dinamizmus. Kölcsönhatás a rendszerek és a technikai haladás között. Közgazdasági Szemle, 57. évf. 1. sz. 1-36. o.

Kőhegyi Gergely-Kiss Hubert János-Selei Adrienn-Zsoldos János [2014]: Koopetíció néhány elméleti és empirikus eredmény egy kooperatív elemeket tartalmazó versenyzői helyzetről. Közgazdasági Szemle, 61. évf. 9. sz. 1000-1021. o.

Krugman, P.-Venables, T. [1995]: Globalization and inequalities of nations. Quarterly Journal of Economics, Vol. 110. No. 4. 857-880. o. http://dx.doi.org/10.2307/2946642. 
Kylanen, M.-Rusko, R. [2011]: Unintentional coopetition in the service industries. European Management Journal, Vol. 29. No. 3. 193-205. o. http://dx.doi.org/10.1016/j.emj.2010.10.006. Lacoste, S. [2012]: Vertical coopetition. The key account perspective. Industrial Marketing Management, Vol. 41. No. 4. 649-658. o. http://dx.doi.org/10.1002/9781118509043.ch9.

Lado, A. A.-Boyd, N. G.-Hanlon, S. C. [1997]: Competition, cooperation, and the search for economic rents. Academy of Management Review, Vol. 22. No. 1. 110-141. o. http:// dx.doi.org/10.2307/259226.

Lawson, R.-Guthrie, J.-Cameron, A.-Fischer, W. C. [2008]: Creating value through cooperation. British Food Journal, Vol. 110. No. 1. 11-25. o.

Lengyel Imre [2000]: A regionális versenyképességről. Közgazdasági Szemle, 47. évf. 12. sz. 962-987. o.

Lengyel ImRe [2010]: A regionális gazdaságfejlesztés. Akadémiai Kiadó, Budapest.

Luo, X. [2007]: A coopetition perspective of global competition. Journal of World Business, Vol. 42. No. 2. 129-144. http://dx.doi.org/10.1016/j.jwb.2006.08.007.

Luo, X.-Rindfleisch, A.-TsE, D. K. [2007]: Working with rivals: the impact of competitor alliances of financial performance. Journal of Marketing Research, Vol. 44. No. 1.77-83. o. http://dx.doi.org/10.1509/jmkr.44.1.73.

Lyon, F. [2000]: Trust, networks and norms. World Development, Vol. 28. No. 4. 663-681. o. http://dx.doi.org/10.1016/s0305-750x(99)00146-1.

Lyson, T. A.-Stevenson, G. W.-Welsh, R. [2008]: Food and a mid-level farm. MIT Press, Cambridge, http://dx.doi.org/10.7551/mitpress/9780262122993.001.0001.

Madhavan, R.-Gnyawali, D. R.-He, J. [2004]: Two's company, three crowds? Academy of Management Journal, Vol. 47. No. 6. 918-927. o.

Major Iván [2014]: Ha elfogy a bizalom... Közgazdasági Szemle, 61. évf. 2. sz. 148-165. o.

MARIANI, M. M. [2007]: Coopetition as an emergent strategy. International Studies of Management and Organization, Vol. 37. No. 2. 97-126. o. http://dx.doi.org/10.2753/imo00208825370205.

MÁtyás Antal [1999]: A modern közgazdaságtan története. Aula, Budapest.

Murphy, J. T. [2006]: Building trust in economic space. Progress in Human Geography, Vol. 30. No. 4. 427-450. o. http://dx.doi.org/10.1191/0309132506ph617oa.

Oum, T. H.-PARK, J. H.-KIM, K.-YU, C. [2004]: The effect of horizontal alliences of firm productivity and profitability. Journal of Business Research, Vol. 57. No. 8. 844-853. o. http:// dx.doi.org/10.1016/s0148-2963(02)00484-8.

Pathak, S. D.-Wu, Z.-Johnston, D. [2014]: Toward a structural view of co-opetition in supply networks. Journal of Operation Management, Vol. 32. No. 5. 254-267. o. http://dx.doi. org/10.1016/j.jom.2014.04.001.

Porter, M. E. [1990]: The Competitive Advantage of Nation. Free Press, New York. http:// dx.doi.org/10.1007/978-1-349-11336-1.

Porter, M. E. [1998]: On competition. Harvard Business School, Boston.

Quintana-García, C.-Benavides-Velasco, C. [2004]: Cooperation, competition, and innovative capability. Technovation, Vol. 24. No. 12.927-938. o. http://dx.doi.org/10.1016/ s0166-4972(03)00060-9.

Ritala, P. [2012]: Coopetition Strategy - When is it Successful? Empirical Evidence on Innovation and Market Performance. British Journal of Management, Vol. 23. No. 3. 307-324. http://dx.doi.org/10.1111/j.1467-8551.2011.00741.x.

Ritala, P.-Golnam, A.-Wegman, A. [2014]: Coopetition-based business models: the case of Amazon.com. Industrial Marketing Management, Vol. 43. No. 2. 236-249. o. http://dx.doi. org/10.1016/j.indmarman.2013.11.005. 
Ritala, P.-Hurmelinna-Laukkanen, P.-Blomevist, K. [2009]: Tug of war in innovation. International of Services, Technology and Management, Vol. 12. No. 3. 255-272. o. http:// dx.doi.org/10.1504/ijstm.2009.025390.

Rusko, R. [2011]: Exploring the concept of coopetition. Industrial Marketing Management, Vol. 40. No. 2. 311-320. o. http://dx.doi.org/10.1016/j.indmarman.2010.10.002.

Sanou, F. H.-Le Roy, F.-Gnyawali, D. R. [2015]: How Does Centrality in Coopetition Networks Matter? British Journal of Management, Vol. 27. No. 1. 143-160. o. http://dx.doi. org/10.1111/1467-8551.12132.

Schulze-Ehlers, B.-Steffen, N.-Busch, G.-Spiller, A. [2014]: Supply chain orientation in SMEs as an attitudinal construct. Supply Chain Management: An International Journal, Vol. 19. No. 4. sz. 395-412. o. http://dx.doi.org/10.1108/scm-07-2013-0241.

Segrestin, B. [2005]: Partnering to explore: The Renault-Nissan alliance as a forerunner of new cooperative patterns. Research Policy, Vol. 34. No. 5. 65-72. 657-672. o. http://dx.doi. org/10.1016/j.respol.2005.02.006.

Smith, W. K.-Lewis, M. W. [2011]: Toward a theory of paradox: a dynamic equlibrium model of organization. Academy of Management Review, Vol. 36. No. 2. 381-403. http://dx.doi. org/10.5465/amr.2011.59330958.

STIEgler, G. [1989]: Verseny. Megjelent: Piac és állami szabályozás. Válogatott tanulmányok. Közgazdasági és Jogi Könyvkiadó, Budapest, 25-45. o.

Tindström, A. [2009]: Causes of Conflict in Intercompetitor Cooperation. Journal of Business and Industrial Marketing, Vol. 7. No. 24. 506-518. o. http://dx.doi.org/10.1108/ 08858620910986749.

Törnroos, J.-Halinen, A.-Medlin, C. J. [2016]: Dimensions of space in business network research. Industrial Marketing Management, megjelenés alatt, http://dx.doi.org/10.1016/j. indmarman.2016.06.008.

TöRÖк А́рÁм [1999]: Verseny a versenyképességért. Miniszterelnöki Hivatal Integrációs Stratégiai Munkacsoport, Budapest.

Valentiny i Ákos [1995]: Endogén növekedéselmélet. Közgazdasági Szemle, 47. o. 6. sz. 582-594. O.

VANHAVERbeke, W.-Noordehaven, N. G. [2001]: Competition between alliance blocks: the case of the RISC microporcessor technology. Organization Studies, Vol. 22. No. 1. 1-30. o. http://dx.doi.org/10.1177/017084060102200101.

Vega-Redondo, F. [1996]: Evolution, games, and economic behaviour. Oxford University Press, Oxford, http://dx.doi.org/10.1093/0198774729.001.0001.

WANG, Y.-Krakover, S. [2008]: Destination marketing. International Journal of Contemporary Hospitality Management, Vol. 20. No. 2. 126-141. o. http://dx.doi.org/10.1108/ 09596110810852122.

Wasserman, S.-Faust, K. [1994]: Social network analysis. Cambridge University Press, New York, http://dx.doi.org/10.1017/cbo9780511815478.

Wilhelm, M. M. [2011]: Managing coopetition through horizontal supply chain relations. Journal of Operation Management, Vol. 29. No. 7. 663-376. o. http://dx.doi.org/10.1016/j. jom.2011.03.003.

Yam, S.-Castaldo, S.-Dugnino, G. B.-Le Roy, F.-Czakon, W. [2010]: Introduction to the coopetition strategies: towards a new form of inter-organizational dynamics. Megjelent: Yam, S.-Castaldo, S.-Dugnino, G. B.-Le Roy, F. (szerk.): Coopetition: Winning strategies for the 21st century. Elgar, Cheltenham-Northhampton, 1-18. o. 